\title{
ENVISIONING FUTURE WARFARE
}

General Gordon R. Sullivan

Colonel James M. Dubik

U.S. Army Command and General Staff College Press Fort Leavenworth, Kansas 1995

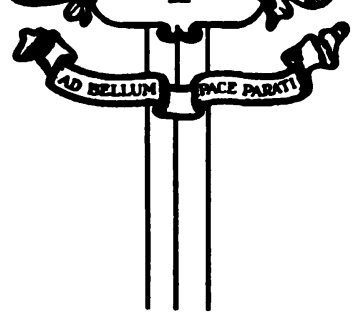

